\title{
Relationship Corporate Social Responsibility, Strategy on Marketing Performance: Value Creation as Mediation
}

\author{
Musfialdy*, Muhammad Soim, \& Edison
}

State Islamic University of Sultan Syarif Kasim Riau, Indonesia

* musfialdy@uin-suska.ac.id

\begin{tabular}{|c|c|}
\hline Article Info & Abstract \\
\hline Received : 2020-01-29 & \multirow{4}{*}{$\begin{array}{l}\text { Social investment by the company will build synergy for people, } \\
\text { organizations, and individual which then build the company's } \\
\text { existence. Social investment using social capital also demands to } \\
\text { support the company's success in finding sustainable profits. This } \\
\text { study aims to analyze the effect Corporate Social Responsibility } \\
\text { (CSR) strategy on marketing performance and value creation as } \\
\text { mediation The samples were } 115 \text { business media company in } \\
\text { Indonesia. The data were collected by interviews and questionnaires. } \\
\text { The data were analyzed by path analysis. The results show that CSR } \\
\text { strategy has affected on value creation. CSR strategy affects } \\
\text { marketing performance. Value creation has effects on marketing } \\
\text { performance. }\end{array}$} \\
\hline : 2020-07-22 & \\
\hline Published : 2020-07-31 & \\
\hline $\begin{array}{l}\text { Key words: CSR strategy; } \\
\text { value creation; marketing } \\
\text { performance }\end{array}$ & \\
\hline
\end{tabular}

\section{INTRODUCTION}

To earn profits sustainably, companies must invest not only materials such as funds, infrastructure, operating systems, and human resources but also a social investment to synergistically support in finding sustainable profits (Adam et al, 2008). Social investment is an investment involving aspects of people's lives aimed at obtaining profits (Sylvie, 2007). For organizations, social capital will enable humans to cooperate to produce. Individually, a high social capital will advance a person's career and compensation obtained by workers is also influenced by their social capital (O'Sullivan et al, 2009). Thus, those imply that social capital is important. Successful social investments will synergically earn the benefits for the community, organizations, and individuals so that the company's existence becomes stronger (Schniets \& Epstein, 2004).

Researches on the implementation of integrated CSR in the business system which is related to the processes that take place in company management are still rarely done. Likewise, the focus of the business world that places CSR activities in an integrated management process as one of the supporting instruments for achieving business goals is still rarely done. Research conducted by Husted and Allen (2007) states that CSR can be a source of kindness, innovation, competitive advantage, and value creation. Then the results of CSR implementation on performance should be positive. If CSR cannot provide a significant influence on performance, there must be a problem in its implementation. Previous studies obtained varied results after implementing a CSR strategy. Some of them contribute positively to the company's financial performance, but some others are negative, and there is no relationship between the company's financial performance and CSR strategy. For this reason, corporate executives seem to doubt to integrate CSR strategy in the management process to achieve business goals.

A strategist an according to Husted and Allen (2007) asserts that CSR can be a source of kindness, innovation, competitive advantage and value creation. Then the results of CSR implementation on performance should be positive. If CSR cannot provide a significant influence on performance, there must be a problem in its implementation. Reviewing Porter's statement, the researcher assumes that further research is still needed, especially to provide strong evidence that CSR activities managed in an integrated management position by involving 
special personnel who handle CSR professionally can influence performance. If that evidence is found, it is likely that CSR will get a strong response from the business community and will be a source of motivation for the company to integrate it into the company's management process.

The integration of CSR into corporate strategy can be done when strategic planning is prepared and it is determined that CSR becomes an integrated part of the company's marketing strategy (Neill \& Gregory, 2006). Considering Porter's theory that strategy covers the strategy of cost leadership, differentiation, and focus, so if CSR is included in the part of the strategy. CSR will become part of the differentiation strategy because CSR activities will be an element of corporate differentiation from its competitors. Implementation of integrated CSR programs as part of marketing planning and implementation activities will make the image of a company different from other companies that do not implement or only implement CSR implementation only as a social responsibility besides the main activities of the business.

Researchers' interest in discussing print off events as an example of CSR strategies implementation is based on a unique and interesting phenomenon. From a dialogue when the researchers visited one of the leading newspaper offices in Indonesia, the Business Media Company, it is known the print off events was held by the Business Media Company for more than ten years, especially during the events, the sale of the largest national newspaper published from Jakarta has increased. This information makes researchers want to know deeper, regarding the conceptual correlation between the strength of CSR differentiation strategies and marketing performance in the Business Media Company. Besides, the researcher also wanted to find out more about why and how CSR projects are carried out by Business Media Company management. Research gaps were also still often found including the results of researches by Husted and Allen (2007), Amalric (2006), Besley and Ghatak (2007), Chang and Wang (2007), Perrini (2005), Savitri (2018) stating that CSR affects directly to financial. In the research of Orgad \& Dawid (2005), Roholah et al (2014), Levis (2006), Capriotti and Moreno (2007), Bhimani \& Soonawalla (2005), Shnayder and Van Rijnsoever (2018), Ingebleek et al (2007) found a negative relationship between social performance and financial performance and also the emergence of the phenomenon of print off events organized by the Business Media Company that is a link and match between theory and practice. For this reason, it is interesting to research Business Media Company. Furthermore, this study aims to examine whether the print off event in the Business Media Company can be used as a reference in CSR implementation and can be seen as an ideal projected link and match between CSR theory and practice.

CSR integration is interpreted by researchers by integrating CSR into one of the marketing strategies in the company as the differentiation strategy. In this case, researchers have not found in previous studies that CSR strategy can further improve marketing performance. The focus of this research is to see whether there is an influence of CSR strategies on value creation, the effect of CSR strategies on marketing performance, and the effect of value creation on marketing performance. The purpose of this study is to analyze the effect of CSR strategies on value creation, the effect of CSR strategies on marketing performance and the effect of value creation on marketing performance. The results show that CSR strategies affect marketing performance. CSR strategies affect the creation of value. Value creation affects marketing performance.

\section{THEORETICAL FRAMEWORK AND HYPOTHESIS}

In the research of Husted and Allen (2007), CSR strategy effect on the value creation variable. Then, value creation became a mediating variable and its effect on marketing performance. The previous one was carried out on large companies in Spain, while this research was conducted on the largest media company in Indonesia. In According the theory of legitimacy that the corporate social contract with the communities in which the company operates and uses 
economics resources. However, due to the theoretical basis used in testing to determine the effect of CSR strategies using the same dimensions and indicators from the research of Husted and Allen (2007) which results in positive findings as a positive effect of dimensions of CSR strategy variables on value creation, the researcher believes that the CSR strategy will also have a positive effect on the value creation variable. Therefore, the hypothesis of the relationship between the CSR Strategy variable and the value creation variable is follows:

H1: CSR Strategy can effect to value creation.

Several empirical studies have confirmed that the relationship between strategy variables and performance is a positive influence relationship. Werther and Chandler (2007), Szekely and Knirsch (2005), concluded that the market can reward companies for their social activities. Then, a negative relationship between social performance and financial performance was found. According to the theory of legitimacy that the processes to provide an appropriate response to social issues. Therefore, the strategy in this study is also predicted to affect marketing performance. This defines that social activities in the form of CSR implementation are believed to provide economic benefits to the company. The other studies that found that CSR affects financial performance such as the research of Schniets \& Epstein (2004) which states that CSR strategic practices imply an effort to maximize profit in the long term. So conceptually, although there are still disputes about the effect of CSR on performance, as expressed by Husted and Allen (2007) and Henderson (2007), most of the latest research states that CSR has a positive effect on performance. Therefore the CSR strategy variables in this study are also predicted to affect marketing performance. Thus, in this study the hypothesis was formulated between CSR strategies on marketing performance, that is:

$\mathrm{H} 2$ : Strategy of CSR can effect marketing performance.

\section{RESEARCH METHODS}

The Samples in this study are 115 business media company in Indonesia during the 2016-2018. Data sources used are primary data and secondary data. Data collecting used surveys with the interview and questionnaire techniques The data were analyzed by path analysis.

\section{RESULTS}

The results of hypothesis testing between CSR strategy variables towards value creation are shown in Table 1. This table shows the path coefficient, $\mathrm{p}$-value, and significance of the variables.

\section{Path Model 1}

Table 1. Coefficients Model 1

\begin{tabular}{lcccccc}
\hline \multirow{2}{*}{ Variable } & \multicolumn{2}{c}{ Unstandardized Coefficients } & Standardized Coefficients & \multirow{2}{*}{ t } & \multirow{2}{*}{ Sig } \\
\cline { 2 - 3 } & $\mathrm{B}$ & Std. Error & Beta & & \\
\hline Constant & 8.257 & 2.199 & & 3.755 & 0.000 \\
Strategi CSR & 0.102 & 0.074 & 0.177 & & 1.375 & 0.022 \\
\hline
\end{tabular}

In the coefficients table, it can be seen that the significance value of the variable CSR strategy is 0.022 which is smaller than 0.05 . These results show that CSR strategy variables significantly affect value creation. 
Table 2. Determinant Variable Model 1

\begin{tabular}{crrrr}
\hline \multicolumn{5}{c}{ Model Summary } \\
\hline Model & R & R Square & Adjusted R Square & Std. Error of the Estimate \\
\hline 1 & 0.22 & 0.630 & 0.330 & 0,862
\end{tabular}

The value of R Square in the "Model Summary" table is 0.630. This means that the effect of $\mathrm{X}$ on $\mathrm{Z}$ is $63 \%$. Meanwhile, for the value of e1 can be calculate with the formula $\mathrm{e} 1=\sqrt{ }$ $(1-0.63)=0.608$. Thus, the diagram of path structure model 1 was obtained as follows:

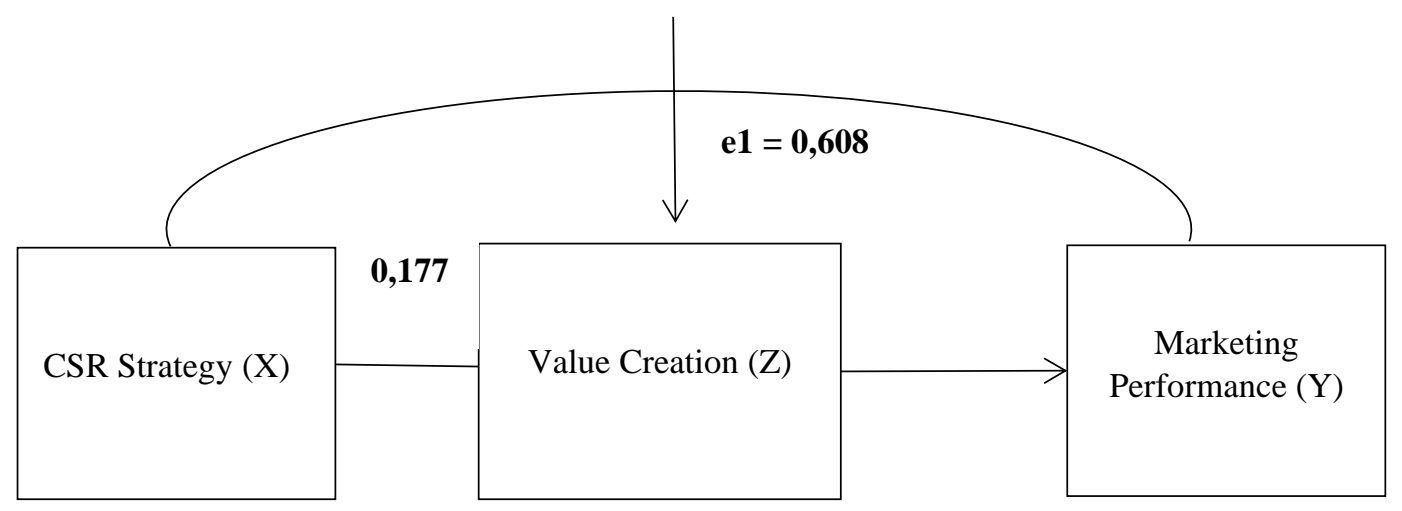

Figure 1. Path structure model 1

Table 3. Determinant Variable Model 2

\begin{tabular}{ccccc}
\hline Model & $\mathrm{R}$ & R Square & Adjusted R Square & Std. Error of the Estimate \\
\hline 1 & 0.177 & 0.520 & 0.510 & 0.858 \\
\hline
\end{tabular}

In the coefficients table, it can be seen that the significance value of the CSR strategy variable is 0.520 and the Value Creation variable is 0.017 ; each of which is smaller than 0.05 . These results show that the variables of CSR strategy and value creation significantly affect marketing performance.

The value of R Square in the "Model Summary" table is 0.520 . This means that the influence of variables $\mathrm{X}$ and $\mathrm{Z}$ on $\mathrm{Y}$ is $52 \%$. Meanwhile, the value of e2 can be calculate using the formula e $2=\sqrt{ }(1-0.52)=0.692$. Thus, the diagram of path structure model II was obtained as follows:

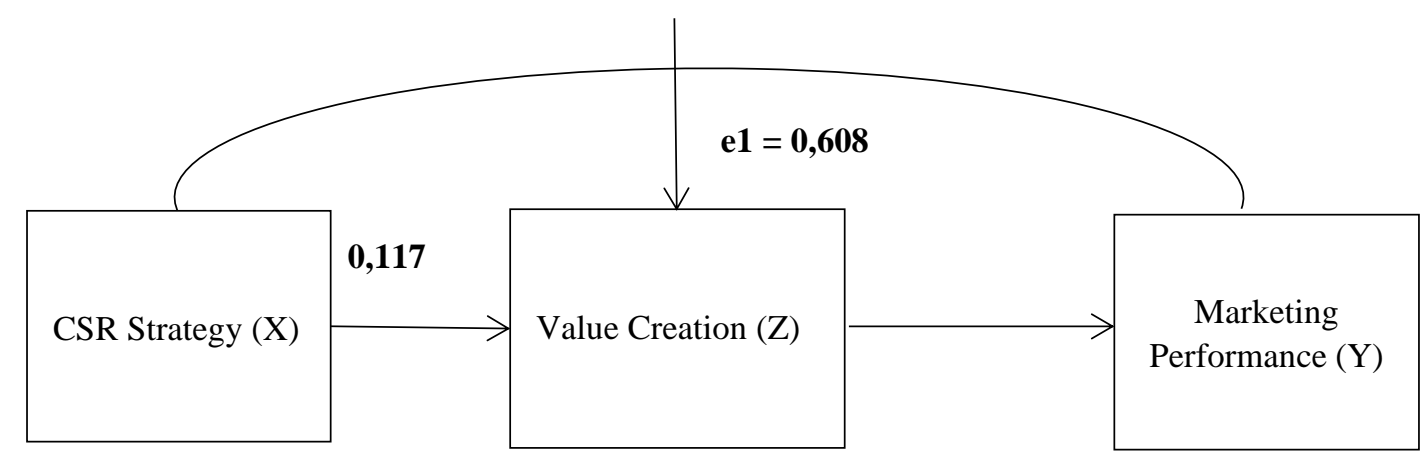

Figure 2. Path structure model 2 


\section{Results of Path Analysis}

Table 4. Statistics of Path Analysis

\begin{tabular}{|c|c|c|c|c|c|}
\hline \multirow{2}{*}{ Variable } & \multicolumn{2}{|c|}{ Unstandardized Coefficients } & \multirow{2}{*}{$\begin{array}{c}\text { Standardized Coefficients } \\
\text { Beta }\end{array}$} & \multirow{2}{*}{$\mathrm{t}$} & \multirow{2}{*}{ Sig } \\
\hline & $\mathrm{B}$ & Std. Error & & & \\
\hline Constant & 12.890 & 1.921 & & 6.711 & 0.000 \\
\hline CSR Strategy & 0.110 & 0.073 & 0.138 & 1.504 & 0.036 \\
\hline Vakue Creation & 0.157 & 0.099 & 0.159 & 1.583 & 0.017 \\
\hline
\end{tabular}

Analysis of the Effect of CSR Strategy (X) on Marketing Performance (Y) from the above analysis obtained a sig value of $X=0.036<0.05$. It can be concluded that there is a significant direct effect X on Y. Analysis of the Effect of CSR Strategy (X) on Value Creation (Z). Analysis of the Effect of Value Creation (Z) on Marketing Performance (Y) obtained a significant value of $Z=00.17<0.05$. So, it can be concluded that there is a significant direct effect of $\mathrm{Y}$ on $\mathrm{Z}$.

\section{DISCUSSION}

CSR strategy mainly focuses on the feasibility of the CSR program which causes high-value creation to be obtained. It can be seen from the high number of new customers to be obtained so that it will indirectly result in high marketing performance and higher sales growth. The results show that the higher the CSR strategy will indirectly affect the higher the marketing performance through the relational reward. The better identification of consumers to the company will result indirectly in high marketing performance and higher sales growth. The result of this study is supported by research from Schniets \& Epstein (2004). CSR strategy affect value creation. The Stronger the CSR Strategy the more Increasing Value Creation of the Company. CSR strategy is measured by three aspects namely feasibility, financial benefits and the principle of willingness, where the aspect of feasibility is the most important measure of CSR strategy. This indicates that the high value of CSR strategy can be seen from the feasibility of CSR programs. The results indicate that the higher the CSR strategy the higher the positive effect on value creation. This shows that if there is an improvement in the CSR strategy which is mainly seen from the feasibility of the CSR program, it will result in high-value creation to be obtained, which can be mainly seen from the high number of new customers. The results of this study support the theory by Nwokah (2009) that corporate strategy can have a long impact. Based on this statement, the effect of corporate strategy can be interpreted to create certain value for the company and contribute to long-term relational reward. Thus, CSR projects implemented as a corporate strategy in the Business Media Company will also have implications for value creation and relational reward. The higher the CSR strategy, the higher the value creation (Henderson, 2007).

Value creation affects marketing performance. Value creation is measured by four aspects including influencing consumer purchasing decisions, getting new customers, developing new products and services, and opening new markets. Getting new customers is the most important measure of value creation. This indicates that high-value creation is seen in the aspect of getting new customers. Hypothesis test results show that marketing performance is measured by three aspects namely market share, sales growth, and profitability. The aspect of sales growth is the most important measure of marketing performance. This shows that the high performance of marketing can be seen from the aspect of sales growth. The higher the value creation will have a positive effect on higher marketing performance. This shows that if there is an improvement in value creation that is primarily seen from the high company getting new 
customers, it will result in high marketing performance and higher sales growth. The results of this study support research conducted by Nwokah (2009) and research conducted by O'Sullivan et al (2009) as well as Neill and Gregory (2006).

\section{CONCLUSION}

CSR programs can affect marketing performance if they are integrated into one of the company's strategies. Implementation of CSR strategies can effectively improve marketing performance if it is done through efforts to increase value creation because the success in increasing value creation will mediate the effectiveness of CSR strategies in improving marketing performance. CSR strategies in Business Media Company cannot be categorized as excellent or superior strategies. This is due to respondents' views on CSR strategies on neutral criteria so that it can be concluded that CSR projects can only be used as an alternative strategy to support other company strategies in improving marketing performance. CSR strategies cannot be used as the only main strategy in marketing. The implementation of CSR strategies which are activities with social missions turned out to be able to provide commercial benefits. Thus, the synergistic effect between social mission and business mission can be achieved if CSR is properly implemented into the company's strategy. Related social activities will be able to support the company's main business activities.

\section{SUGGESTION}

It is needed to be conducted in different industries both for business and non-business organizations, to obtain more various empirical evidence. Thus, the discussion of CSR implementation will continue to expand in various sectors, both profit and non-profit. Therefore, the strength of CSR strategies, in the long run, should be done by creating new events that are very attractive or old events that are constantly being modified so as not to reduce the strength of its appeal to become news items published in the newspaper. Business practitioners should implement CSR projects by integrating them into a part of the company's strategy so that CSR implementation can affect marketing performance improvement. Considering that CSR programs become an important part for stakeholders, and CSR integrated into marketing strategies has social and business effects synergistically, so marketing managers should immediately place CSR strategies as part of marketing strategies to support targeted performance improvement.

\section{Reference}

Adam, S. Andre, V., \& David, B. (2018). The World In Modern Marketing's Contribution to Organizational Performance. Marketing Intelligence \& Planning, 27, (1), 7-24.

Amalric, F. (2006). Pension Funds, Corporate Responsibility, and Sustainability. Ecological Economics, 59(4), 440-450. https://doi.org/10.1016/j.ecolecon.2005.11.009

Besley, T., \& Ghatak, M. (2007). Retailing Public Good: The Economics of Corporate Social Responsibility. Journal of Public Economics, 91, 1645-1663.

Bhimani, A. \& Soonawalla, K. (2005). From Conformance To Performance: The Corporate Responsibilities Continuum. Journal of Accounting And Public Policy, 24(3), 165-174. https://doi.org/10.1016/j.jaccpubpol.2005.03.001

Capriotti. P., \& Moreno. A. (2007). Corporate Citizenship and Public Relations: The Importance and Interactivity of Social Responsibility Issues on Corporate Website. Public Relations Review, 33(1), 84-91. https://doi.org/10.1016/j.pubrev.2006.11.012 
Chang, C.S, \& Wang, F.C. (2007). The Effect of Product Diversification Strategies on The Relationship Between International Diversification and Firm Performance. Journal Of World Business, 42, 61-79. https://doi.org/10.1016/j.jwb.2006.11.002

Schniets, K., \& Epstein, M. (2004). Does Corporate Social Responsibility Pay Off. Graziadio Business Review, 7(2), 1-7.

Henderson, J.C. (2007). Corporate Social Responsibility and Tourism: Hotel Companies in Phuket, Thailand, After the Indian Ocean Tsunami. International Journal Of Hospitality Management, 26, 228-239. https://doi.org/10.1016/j.ijhm.2006.02.001

Husted. W.B., \& Allen. D.B. (2007). Strategic Corporate Social Responsibility and Value Creation Among Large Firms Lessons From the Spanish Experience. Long Rang Planning, 40(6), 594-610. https://doi.org/10.1016/j.lrp.2007.07.001

Shnayder, L., \& Van Rijnsoever, F.J. (2018). How Expected Outcomes. Stakeholders, and Institutions Influence Corporate Social Responsibility at Different Levels of Large Basic Needs Firms. Business Strategy and The Environment, 27(8), 1689-1707. https://doi.org/10.1002/bse.2235

Ingebleek, P., Menno, B., \& Goddijn, S. (2007). Setting Standart For CSR: A Coparative Case Study on Criteria-Formulating Organization. Journal Of Business Research, 60(5), 539-548. https://doi.org/10.1016/j.jbusres.2007.01.004

Levis, J. (2006). Adoption of Corporate Social Responsibility Codes By Multinational Companies. Journal of Asian Economic, 17(1), 50-55. https://doi.org/10.1016/j.asieco.2006.01.007

Neill, S., \& Rose, G.M. (2006). The Effect Of Strategy Complexity on Marketing Strategy and Organizational Performance. Journal Of Business Research. 59(1), 1-10. https://doi.org/10.1016/j.jbusres.2004.12.001

Nwokah, N.G. (2009). Costumer-fokus, Competitor-fokus and Marketing Performance. Measuring Business Excellence, 13(3), 20-28. https://doi.org/10.1108/13683040910984293

Roholah, M., Afshari, R., Ghadimi, Z., Mohammadi F., \& Asadi, N. (2014). The Influence of Export Skills on Export Performance: A Case Study of Export Companies in East Azerbaijan. International Journal of Organizational Leadership, 3, 80-91.

O'Sullivan, D., Abela V.A., \& Hutchinson, M. (2009). Marketing Performance Measurement and Firm Performance. European Journal of Marketing, 43(5/6), 843-862. https://doi.org/10.1108/03090560910947070

Orgad, S.M., \& David, M. (2005). Sustainable Edges: CSR, Post Modern Ply, And SMEs. Public Relations Review, 31, 578-583. https://doi.org/10.1016/j.pubrev.2005.08.019

Sylvie, L., (2007). Size, Strategic, and Market Orientation Effects on Innovation. Journal of Business Research, 61, 753-764. https://doi.org/10.1016/j.jbusres.2007.08.002

Perrini, F. (2005). Building A European Portrait of Corporate Social Responsibility Reporting. European Management Journal, 23(26) 611-627. https://doi.org/10.1016/j.emj.2005.10.008

Savitri, E. 2018. Relationship Between Family Ownership, Agency Costs Towards Financial Performance and Business Strategy as Mediation. Business: Theory and Practice, 19(49-58) https://doi.org/10.3846/btp.2018.06

Szekely, F., \& Knirsch, M. (2005). Responsible Leadership And Corporate Social Responsibility: Metrica For Sustainable Performance. European Management Journal, 23(6), 628-647. https://doi.org/10.1016/j.emj.2005.10.009 
Werther, B.W., \& Chandler, D. (2007). Corporate Social Responsibility Strategy as Global Merk Quarante. Journal Of Business Research, 58, 239-248. 